\title{
CHAPTER FIFTEEN
}

\section{GALEN'S READING OF THE \\ HIPPOCRATIC TREATISE THE NATURE OF MAN: THE FOUNDATIONS OF HIPPOCRATISM IN GALEN}

\begin{abstract}
More than any other medical writer from Greek antiquity, it was Galen who by means of his extensive œuvre-which comprises more than ten percent of all Greek literature that has survived from Homer to the end of the second century $\mathrm{AD}$ - contributed most effectively to the spread of the work attributed to his precursor, Hippocrates, a doctor from the fifth century BC, whom he considers the most eminent of all the ancient doctors who preceded him. ${ }^{*}$ In particular, he wrote commentaries on several Hippocratic treatises, amongst them a commentary on The Nature of Man. ${ }^{1}$

I have selected this commentary as the subject of this paper, firstly because The Nature of Man has remained the most famous Hippocratic work in Western medicine, since it discusses the humoral theory associated
\end{abstract}

\footnotetext{
* This paper is part of a series of studies on Galen's reading of Hippocrates that I have carried out, either in collaboration with Véronique Boudon, or alone. The first discussed an aspect of therapeutics (J. Jouanna and V. Boudon, "Remarques sur la place d'Hippocrate dans la pharmacologie de Galien," in A. Debru (ed.) Galen on Pharmacology, Philosophy, History and Medicine, Leiden, 1997, pp. 213-234). The second discussed Galen's reading of Hippocratic ethics (J. Jouanna, "La lecture de l'éthique hippocratique chez Galien," in H. Flashar and J. Jouanna (eds.), Médecine et morale dans l'Antiquité, coll. Entretiens sur l' antiquité classique XLIII, Vandoeuvres-Geneva, 1997, pp. 211-253*[also included in English translation as ch. 13 in the present volume]). The third discussed an aspect of nosology (J. Jouanna, "Miasme, maladie et semence de la maladie. Galien lecteur d'Hippocrate," in D. Manetti (ed.) Studi Galenici, Florence, 2000, pp. 39-72). On Hippocratism in Galen in general, see H. Diller, "Zur Hippokratesauffassung des Galen," Hermes 68, 1933, pp. 167181 (= Kleine Schriften, Berlin, 1973, pp. 3-16); id. "Empirie und Logos: Galens Stellung zu Hippocrates und Platon," in K. Döring and W. Kullmann (eds.), Studia Platonica. Festschrift für Hermann Gundert, Amsterdam, 1974, pp. 227-238; G. Harig and J. Kollesch, "Galen und Hippokrates," in L. Bourgey and J. Jouanna (eds.) La Collection hippocratique et son rôle dans l'histoire de la médecine, Leiden, 1975, pp. 257-274 (with bibliography); W.D. Smith, The Hippocratic Tradition, Ithaca-London, 1979, pp. 61-176; G.E.R. Lloyd, Methods and Problems in Greek Science, Cambridge, 1991, p. $398 \mathrm{ff}$;; M. Vegetti, "L'immagine del medico e lo statuto epistemologico della medicina in Galeno," ANRW II, 37, 2, Berlin-New York, 1994, pp. 16721717 .

${ }^{1}$ On Galen's commentaries on Hippocrates, see particularly D. Manetti and A. Roselli, "Galeno commentatore di Ippocrate," ANRW II, 37, 2, Berlin-New York, 1994, pp. 1529-1635.
} 
with Hippocrates, that of the four humours: blood, phlegm, yellow bile and black bile. The second reason is of a more philological nature: I felt it was necessary to work on the basis of a scholarly critical edition of the Greek text. Despite the renaissance of Galenic studies at the end of the twentieth century, several Galenic works are still not available in a scholarly critical edition. This is not the case for Galen's commentary on The Nature of Man. Indeed, we find ourselves in an exceptional situation: we possess a critical edition of both the Hippocratic treatise and Galen's commentary, published in the international collection of the Corpus Medicorum Graecorum; for Galen, that of J. Mewaldt (CMG V, 9, 1, Berlin 1914) and for Hippocrates, that of J. Jouanna (CMG I, 1, 13, Berlin, 1975). However, there is a difference between these two editions: that of Hippocrates includes a translation of the Greek into a modern language (in this case, French), whilst that of Galen includes only the Greek. There is, to my knowledge, no translation in a modern language of Galen's Commentary on Hippocrates' The Nature of Man, which obviously presents a major obstacle to the dissemination and study of this commentary. ${ }^{2}$ The international project of a critical edition of Galen's works in the Collection des Universités de France is in progress, but an edition of this commentary has not yet appeared. I therefore present in this paper my own translation of the passages of Galen that are quoted. Above all, I have chosen Galen's commentary on this treatise because it allows me to reconstruct, better than any other text, before an audience of philosophers, the image that Galen has of Hippocrates and of his role in the history of a philosophical question as fundamental as that of nature, of physis.

Before examining the commentary itself, let us remind ourselves of the structure and technique of Galen's Commentary on Hippocrates' The Nature of Man. It comprises three books (or sections), corresponding to three parts of the Hippocratic treatise: the first book of the commentary corresponds to chapters one to eight of the treatise, where the Hippocratic author critically denounces a monist conception of human nature and affirms that man is formed of four humours (blood, phlegm, yellow bile and black bile), which are mixed when man is in good health and separated when man is sick. The second section of Galen's commentary corresponds to chapters nine to fifteen of The Nature of Man, where the discussions are less coherent

$2 *$ [An English translation of this commentary by W.J. Lewis can be found on http://www .ucl.ac.uk/ ucgajpd/medicina\%2oantiqua/tr_GNatHom.html; a new English translation with introduction and notes (by R.J. Hankinson) is due to appear in 2013 in the Cambridge Galen Translations, edited by P.J. van der Eijk]. 
and more dispersed than in the first part, but where we find in particular a long discussion of the blood vessels that was already famous by Aristotle's time, who quotes it in his treatise History of Animals. ${ }^{3}$ The third section of Galen's commentary corresponds to chapters sixteen to twenty three of the treatise The Nature of Man (which Littré and Jones both published erroneously under the title Regimen in Health). This last section is more coherent than the second part and is dedicated to the diet of people in good health. These are the main divisions found in Galen's commentary on The Nature of Man.

The commentary's technique, which is comparable to that of Galen's other commentaries, is what we call a linear commentary. Galen begins by copying a passage of the Hippocratic text, and then comments on it, before copying another passage of the Hippocratic text and commenting on it. Thus, Galen's work appears as an alternation between what we call the Hippocratic lemmata (the words of Hippocrates that Galen has copied) and the explanations given by Galen. The lemmata that Galen copied are not of equal length, and they can range from a single sentence to an entire paragraph; moreover, Galen did not copy the entire text of Hippocrates, ${ }^{4}$ although he did copy most of it. An unexpected consequence of this technique is that it allows us to reconstruct the Hippocratic work by extracting the Hippocratic lemmata from Galen's explanations. This method of reconstructing the Hippocratic text from Galen's commentary is well known in the Arabic tradition of the school of Hunayn in the ninth century, but it is also attested in the Greek tradition itself, although cases are rarer. ${ }^{5}$ Thus, we

3 Aristotle, History of Animals 3.3, 512a12-513a7.

4 On Galen's incomplete copying of Hippocrates' text, see the recent study by J. Jouanna, Hippocrate II $2^{e}$ partie: Airs, eaux, lieux, CUF, Paris, 1996, p. 142, n. 272; see also id. "Le traité hippocratique du Régime dans les maladies aiguës," RHT 6, 1976, pp. 1-30 (particularly p. 7, n. 2) and previously F. Kudlien, Die handschriftliche Überlieferung des Galenkommentars zu Hippokrates De Articulis, Berlin, 196o, pp. 55-57.

5 The Nature of Man was preserved in the Arabic tradition thanks to reconstruction from Galen's lemmata. See J. Jouanna, Nature de l'homme (1975), pp. 99-107 (particularly p. 104, n. 1). The Arabic text of the treatise, along with an English translation, was published by J.N. Mattock and M.C. Lyons, Hippocrates: On the Nature of Man in Arabic Technical and Scientific Texts, vol. 4, Cambridge, 1968. The same applies to other Hippocratic treatises: Aphorisms, Airs, Waters, Places, Regimen in Acute Diseases, In the Surgery, Generation/Nature of the Child; the Oath; Sevens; see G. Strohmaier, "Der arabische Hippokrates," Sudhoffs Archiv 64, 1980, pp. 234-249 (particularly p. 244f.). On this technique of reconstruction in the Greek tradition see, for example, Parisinus gr. 396 (13 th century), which presents the preamble of Hippocrates' Prognosis, reconstructed from Galen's lemmata; see B. Alexanderson, Die hippokratische Schrift Prognostikon, coll. "Studia Graeca et Latina Gothoburgensia," XVII, Uppsala, 1963, p. 79 . 
can see how Galen's commentaries on Hippocrates have been able to contribute indirectly to the survival of Hippocrates himself through the reconstruction of the Hippocratic Corpus from the Galenic tradition.

To conclude our presentation of Galen's commentary, we should add that the linear commentary is preceded by a long introductory overview of seven pages (ed. Mewaldt, pp. 3-11), that each of the other two sections of the commentary are preceded by a shorter introduction as well (second section, ed. Mewaldt, p. 57; third section, ed. Mewaldt, p. 89) and, finally, that the first section ends with a rather long conclusion on the method and authenticity of this section (Mewaldt, pp. 53-56), whilst the other two sections do not have any particular conclusion. Thus, there are four discussions in the form of overviews, in addition to the linear explanations, although the most important for our purposes are the preamble and the conclusion attached to the first part.

Following this brief overview of the commentary, my paper will focus on three important questions: first, the place of this commentary in Galen's life and work and the commentary's intended audience; second, Galen's discussion of the treatise's authenticity and its impact on the text; third, the philosophical significance that Galen gives to The Nature of Man.

We begin with the place of the commentary in Galen's life and activity as a commentator. We cannot avoid this traditional question, since Galen continually spoke about himself and his work, even in his most technical writings such as his commentaries. ${ }^{6}$ Exceptionally, at the end of his life Galen wrote two works on his own bibliography, his On My Own Books, at the request of his friend Bassus, in which he classifies his works according to their subjects, and the other, The Order of My Own Books, dedicated to Eugenianus, in which he advises a reading order for those who wish to tackle his work. ${ }^{7}$ In both bibliographical works, Galen mentions his commentaries on Hippocrates. In the first, he reports, with great precision, the different commentaries that he has written with the number of books included in each of them. His work as a commentator is considerable. Under the rubric of what Galen calls $\dot{\varepsilon} \xi \eta \eta \dot{\eta} \sigma \varepsilon \mid \varsigma x \alpha \theta^{\prime} \dot{\varepsilon} x \alpha \dot{\sigma} \sigma \tau \nu \nu \alpha \dot{\tau} \tau 0 \hat{v} \lambda \dot{\varepsilon}^{\prime} \xi$ iv, i.e. line

${ }^{6}$ Paul Moraux has contributed significantly to our knowledge of this autobiographical aspect of Galen's work by translating into French the principal passages where Galen speaks of himself and his writings, in a work entitled Galien de Pergame. Souvenirs d'un médecin, published in 1985 in Paris by Belles Lettres.

7 Galen, On My Own Books, ed. I. Mueller, Scripta Minora II, pp. 91-124; On the Order of My Own Books, ibid. pp. 80-90. 
by line commentaries, he lists seventeen commentaries on Hippocratic treatises, each comprising between one and eight books. Most of these commentaries have been preserved in Greek, although some are forgeries; some have been preserved only in Arabic. In this respect, we must highlight a most wonderful recent discovery in an Arabic manuscript in Cairo of the full commentary on Airs, Waters, Places that was lost in Greek; the translation is still not published, but I was able to use it for my edition of Airs, Waters, Places in the Collection des Universités de France in 1996. In this list of commentaries that Galen himself established, the commentary on The Nature of Man comes last. Galen was not content in giving only the number of books, as for the other commentaries, but he adds something extra:

Commentary on The Nature of Man: two books; after they had been written, and after hearing that some people criticised this work (sc. The Nature of Man) as not being authentic, I wrote another three under the following title: "That Hippocrates in his other writings clearly has the same opinion as in The Nature of Man."

Thus after having written his commentary, Galen, noticing continued criticism against the authenticity of The Nature of Man, wrote another work in three books to demonstrate its authenticity another way. This latter work is lost, but from these details it appears that the problem of authenticity played a particularly important role in Galen's approach to The Nature of Man.

Besides the enumeration of Galen's commentaries on Hippocrates with their number of books, Galen's bibliographic work On My Own Books establishes an important distinction between two categories of commentaries, which are distinguished by the date of their composition, their destination and their content. The first series of commentaries (comprising commentaries to Aphorisms, Fractures, Joints, Prognosis, Regimen in Acute Diseases, Wounds, Injuries of the Head, Epidemics 1) belongs to a period when Galen wrote his commentaries either for training purposes or for the private instruction of a particular friend. This corresponds to his first visit to Rome, where he no longer had access to the library he had left behind at Pergamum and where he would have been able to find the commentaries of his predecessors (the years 162-166, under Marcus Aurelius). The second

\footnotetext{
8 See pp. $133^{-148 .}$

${ }^{9}$ Galen, On My Own Books, ed. I. Mueller, Scripta Minora II, p. 113,13-18. Galen's commentary on The Nature of Man contains three books. Hunayn, in his Risala, also recognised three books (ed. Bergsträsser, no. 102, p. 36).
} 
series of commentaries was written for a wider audience and dates from his second stay in Rome (from 168 onwards, under Marcus Aurelius, and then Commodus). Galen now had access to all the documents that he had left at Pergamum during his first trip. It is this second series that includes the commentary on The Nature of Man. Galen quotes this commentary alongside eight others (those on Epidemics 2, Epidemics 3, Epidemics 6, Humours, Nutriment, Prorrhetic, Surgery and Airs, Waters, Places). Thus, there are two variables that explain the different nature of the two categories of commentary: the first relates to the destination of the commentary, the second, more contemporarily, the state of the documentation that Galen could consult. When he did not have access to the commentaries of his predecessors, Galen only rarely referred to their opinion, except when they committed grave errors in their interpretation, and he restricted himself to giving his own personal commentary. Moreover, when he wrote his commentaries for a particular friend, he could take into account his level of culture and leave out of his commentary what its recipient already knew. By contrast, in the second category of commentaries, when Galen had a group of various readers, rather than a particular reader, in mind (even if he dedicated his work to a particular person), he explained everything without presupposing any previous knowledge of the reader. Elsewhere, when he had access to the commentaries of his predecessors, he could present a commentary that was not only personal, but also critical and complete.

We find confirmation that the commentary to The Nature of Man belongs to the second category in the start of the preamble (ed. Mewaldt, p. 3,4-19):

A long time ago, when I gave the work I had written on the elements according to Hippocrates to one of my friends who was going abroad, I tailored it towards his level of culture. I therefore did not offer any demonstration for the things of which I knew he had an accurate understanding at the start of the text, nor even gave a summary of it, as I tend to do when my discussion is destined to be presented to all those who will read it. Since this work, in ways I do not understand, fell into the hands of a number of other people, I did not think it prudent to write a second treatise in addition to this one. This was, however, also the reason why I postponed writing a commentary on the book The Nature of Man, because all the principal points had been clearly discussed thanks to this previously published treatise, which is called The Elements According to Hippocrates. But now, since my friends have asked me to supply them with the exegesis of the Hippocratic treatise itself, not only on the passages indispensable for the understanding of its doctrine, as I had already provided in the other work, but on all the passages in order, I will begin by first writing those things which I had omitted to say at the start of The Elements According to Hippocrates, since I knew that my friend was already familiar with them. 
This passage, whilst giving us a good example of the author's presence in his work, illustrates the distinction between the two categories of commentaries that Galen wrote; and here the distinction is applied exceptionally to two commentaries on one and the same Hippocratic treatise. We clearly recognise in this preamble the distinction between a commentary destined for a friend and a commentary destined for a wider public. Regarding The Nature of Man, Galen composed a first commentary destined for one of his friends, the treatise called The Elements according to Hippocrates, a treatise that has been preserved and that was published by the American scholar De Lacy in the $C M G$ in 1996. Then Galen wrote a second commentary for his friends (in plural!), this time for a larger audience. This difference in audience explains, according to Galen, the absence of certain discussions in the first work, discussions that were not necessary because he was aware that his reader already knew them. Thus, we find careful considerations here on the part of the author concerning the difference in his writing with regard to the audience he was addressing. The two treatises are also differentiated by the method of their commentary. The treatise The Elements according to Hippocrates, whilst drawing on sentences from The Nature of Man, is a synthetic commentary, whilst the later commentary on The Nature of Man is a commentary that explains the expressions 'in order', as Galen himself says, i.e. line by line. It was the existence of the first commentary, Galen adds, that led him to postpone the redaction of the second. The linear commentary on The Nature of Man is probably one of the last two Hippocratic commentaries written by Galen, the second being the commentary to Airs, Waters, Places, and it might even be the very last, around $190 \mathrm{AD}$, during the final years of the reign of Commodus..$^{10}$

Having considered the place of the treatise in Galen's work and life, and its destination as a work meant for a wider public, we come now to one of the aspects of the commentary that explains its structure and determines the view that the author has of the Hippocratic treatise, namely the problem of its author. We have seen that after writing his commentary, Galen felt the need to return to the question of the work's authenticity due to the scepticism of some people, in a work that is unfortunately lost. For Galen, it is a crucial question that affects his overall interpretation of the Hippocratic treatise The Nature of Man.

\footnotetext{
10 See J. Ilberg, “Über die Schriftstellerei des Klaudios Galenos I," Rheinisches Museum 44, 1889, p. 236.
} 
During Galen's lifetime in the second century AD, the Hippocratic question, i.e. the problem of attributing treatises to Hippocrates, was already openly disputed. It is certain that of the sixty or so medical treatises collected under the name of Hippocrates, not all of them could have been written by Hippocrates because of differences in style or doctrine. Even though people in Galen's time were less sceptical than today on the Hippocratic question, they nevertheless debated the origins of certain treatises. Galen had himself written a treatise, now lost, called The Authentic and Spurious Writings of Hippocrates. This treatise predated his commentary on Hippocrates' The Nature of Man, because Galen refers to it in his commentary and even quotes a long passage he had written in the previous treatise on the authenticity of The Nature of Man. ${ }^{11}$ Galen quotes in his Commentary on Hippocrates' The Nature of Man what he had previously written because his position had not fundamentally changed. In his The Authentic and Spurious Writings of Hippocrates he pointed out that The Nature of Man was composed of several parts through a process of revision and merging: the first part on the elements and humours was completely in accordance with Hippocrates, as was the last part on regimen; by contrast, in the middle part, certain passages were interpolated, in particular the description of the blood vessels, because it does not agree with visible phenomena and it is inconsistent with the description of the blood vessels in Epidemics 2, which Galen attributes to Hippocrates. ${ }^{12}$ Thus, when he wrote The Authentic and Spurious Writings of Hippocrates, Galen saw The Nature of Man as a composite treatise, whose main part was, however, written by Hippocrates.

Yet in his Commentary, Galen does not just quote what he has already written, but thoroughly retackles the problem. In the preamble, Galen notes that a small minority denied its authenticity, about which he is indignant, but he explains this error by the composite character of the Hippocratic work. He also notes that certain people did not attribute it to the master Hippocrates, but to his student, Polybus, something which does not make a lot of difference in Galen's eyes, because Polybus is reported to have changed nothing of Hippocrates' doctrines in any of his works (although it remains unclear how Galen knows this). After the preamble, Galen devotes the synthetic parts of the three sections (the conclusion of the first section and the two introductions to the remaining sections) to resolving the problem of its authenticity and to proposing a rather personal

\footnotetext{
${ }^{11}$ Galen, In Hippocratis De natura hominis, ed. Mewaldt CMG V 9, 1, pp. 7,19-8,18.

12 The description of blood vessels in Epidemics 2 is in chapter one of section four (5.120,13-124 L.).
} 
solution. Galen does not attribute the same status to the three parts he distinguishes in The Nature of Man and which correspond to the three divisions that he makes in his Commentary. He regards the first part on the elements of the nature of man (chapters one to eight) as the work of the master Hippocrates and the last part on regimen by his student Polybus. Thus, we note a slight difference compared to the position he previously upheld in his The Authentic and Spurious Writings of Hippocrates. Whilst in his work on the Hippocratic question he connects the first and last part by saying that they are from the hand of Hippocrates (first part = ed. Mewaldt,

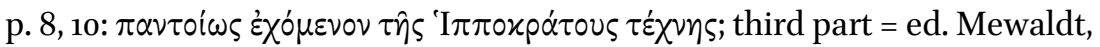

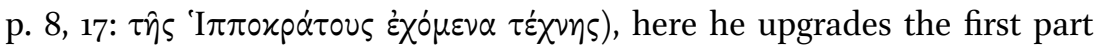
by attributing it to Hippocrates, openly opposing those who believe the whole treatise to be inauthentic, and slightly downgrades the last part by attributing it to his student Polybus. Of course, this change in opinion on the attribution of the last part is not fundamental to Galen, because he holds that Polybus did not change the theories of Hippocrates; instead, it is probably a concession to those who attribute the entire treatise to Polybus. For the middle part of the Hippocratic treatise (chapters nine to fifteen), Galen now holds a more radical position than he used to have. Some passages which he had previously judged to be in agreement with the Hippocratic art, along with the first part (such as the distinction between epidemic and sporadic diseases), seem now less correct to him. On the causes of epidemic disease, he chastises the author of the passage for having taken into account only the pathogenic emanations contained in the air, without also considering, as Hippocrates does in his Epidemics, either a generally unhealthy diet or an imbalance in the elemental qualities of the air without the presence of pathogenic elements. But above all, Galen is no longer content with establishing the composite character of The Nature of Man; he reconstructs the history of its creation. He attributes the middle part to a forger who had brought together two smaller books that were previously separate: the short work The Nature of Man by Hippocrates that forms the first part of the treatise and the short work Regimen in Health by Polybus that forms the last part of the treatise. Galen presents this reconstruction not as a hypothesis, but as a fact, which he skilfully inserts into the history of the book during the Hellenistic period. Here is what he says in the introduction to the second part of his Commentary (ed. Mewaldt, p. $57,12-20)$ :

Indeed, in the era of the kings of the line of Attalus and those of the line of Ptolemy, as they competed with each other for the acquisition of books, there began to arise a certain recklessness in the (false) attribution and compilation 
of them by those who, in order to get money, brought books by famous authors to the kings. Since both of the two books The Nature of Man and Regimen in Health, were short, someone, thinking that each of these two might be disregarded for its shortness, combined the two volumes into one; and some other, or perhaps the person who first combined them, inserted certain discussions amongst them.

Thus it was in the Hellenistic period that the The Nature of Man had been put together by the merging of two works taken from the school of Hippocrates, the School of Cos, undertaken by one or two forgers in order to obtain a better price from the court of Pergamum or Alexandria. In support of this historical fiction, Galen sustains that the lengthy description of the blood vessels comprising four pairs of vessels descending from the head, found in what he believes to be the interpolated section, is wholly unworthy of Hippocrates and contradicts the system of two major vessels described in Epidemics 2, which Galen attributes to Hippocrates. Galen picks up the argument that he had previously made in his The Authentic and Spurious Works of Hippocrates; but to further lambast this outrageous description of eight vessels coming from the head, he launches into a lengthy enumeration of all the doctors who preceded him and in whom there is no such stupidity (ed. Mewaldt, pp. 69,30-70,17).

For no other doctor argued that there are eight vessels leading from the head down into the lower parts of the body, neither amongst those who practised dissection less carefully, nor among those who practised it more carefully, neither Diocles, nor Praxagoras, nor Erasistratus, nor Pleistonicus, nor Philotimus, nor Mnesitheus, nor Dieuches, nor Chrysippus, nor Aristogenes, nor Medeius, nor Euryphon, nor any other of the ancient physicians. What more need we say about those who came after them who made the greatest advances in anatomical observation, like Herophilus and Eudemus, to whom no one has yet added any discovery in methodology, up to Marinus and Numisianus? Or Heracleianus, whom I knew in Alexandria, and who is not without importance. There are many students of these men; but the most famous are my teacher Pelops, the student of Numisianus, and Quintus, student of Marinus. Of course, Quintus did not write a book on anatomy, nor any other work; but from all the others we have no small number of books on anatomy; there are also anatomical writings by the students of Quintus, such as Satyrus, our teacher, and Lycus. Of all of these, and of the others who have written books on anatomy besides them, no one recognises four pairs of vessels leading from the head.

Galen is not content with quoting all the doctors that concerned themselves with anatomy before him to confound the author of such a description, but he pursues it with sarcasm, comparing his error with that of mistakenly counting the hills of Athens or Rome (ed. Mewaldt, p. 70,17-23). 
This statement (i.e. the statement that there are eight vessels descending from the head) is similar to saying that Athens has eight acropoleis, whilst in reality there is only one. It is like someone saying that there are eight or six hills at Rome; in each case, he is out by one; but if he said that instead of seven there was only one hill that was inhabited, or conversely that at Athens there were eight instead of one, he would be far more wrong than the person who had been mistaken only by one.

Not content with ridiculing the author of this description of blood vessels by comparing his error to saying there are eight hills in Athens instead of one, or one at Rome instead of seven, Galen also calls him four times a new Prometheus and, moreover, a "new Prometheus who talks drivel."13 He compares his discussion of the blood vessels that descend from the

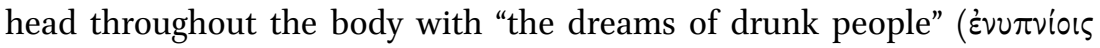

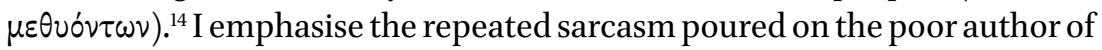
this description of the blood vessels not only to give an idea of the vivacity of Galen's polemic talent, but also to highlight an incredible blunder of Galen who omitted a crucial witness: Aristotle. We have already said that Aristotle, in his History of Animals, quotes this entire description of blood vessels and attributes it to Polybus. ${ }^{15}$ Which Polybus can this be, if not the student of Hippocrates? Thus, the entire fiction of Galen on the genesis of The Nature of Man collapses. This passage that Galen thinks was added by a rapacious fraudster in the Hellenistic period was already known by Aristotle, who attributed it to Polybus. Thus, the modern critic cannot believe Galen's tale on the origin of The Nature of Man.

However, this fiction has influenced readings of the Hippocratic treatise to such an extent that it has left traces in modern scholarship that seem difficult to overcome. Galen's theory of the origin of the Hippocratic treatise led editors of Hippocrates from the sixteenth century to the nineteenth century, in particular the edition of Littré (1849), to edit the two works separately, firstly The Nature of Man, and then Regimen in Health, which the manuscripts present under the single title The Nature of Man. Yet in so doing the editors have adopted an unfortunate division, since they divide into two what Galen divided into three, publishing under the title The Nature of Man both the first part, which Galen considered authentic, and the second, which he considered apocryphal and, under the title Regimen in Health,

\footnotetext{
13 Ed. Mewaldt, p. 75,1.

14 Ed. Mewaldt, p. 73,18.

15 Aristotle, History of Animals 3.3, 512a12-513a7.
} 
the final part on regimen that Galen attributed to Polybus. Although inspired by the division established by Galen, the editors of Hippocrates did not really appreciate the sense of this division. At any rate this separation is not justified by the manuscripts of Hippocrates, but is the application of Galen's view of the origins of the Hippocratic treatise to the editing of Hippocrates. Here is a good example of the impact of a commentary on the text that is commented on. Regimen in Health is a fiction that originates with Galen, but that nevertheless continues. Although this erroneous distinction had been denounced in the first critical edition published in the twentieth century by Oscar Villaret in 1911, the Loeb edition by W.H.S. Jones, published in 1931, still presented the two treatises separately, as Littré had done. Although my critical edition published in $C M G$ in 1975 again denounced this distinction, the editions of Littré and Loeb still mislead many scholars who, not being specialists in the Hippocratic Corpus, need to use Hippocrates.

However, the problem of authenticity in Galen's Commentary does not come down solely to historical fiction. To demonstrate the authenticity of the first part of the treatise on the elements in The Nature of Man, Galen, who was content simply to say in his The Authentic and Spurious Works of Hippocrates that it agrees with Hippocrates' art, now produces a new argument based on the place of Hippocrates in the philosophical inquiry into physis, particularly the connections between Hippocrates and Plato. Thus from a historical novel, we pass to the third part, to Galen's view of the history of philosophy and of the place of Hippocrates' medicine in this history.

Indeed, a large part of the preamble is occupied with a discussion of what is meant by physis, a term that gave the title of physikoi to certain ancient philosophers. It seems necessary to quote the whole discussion, despite its length, before commenting on it (ed. Mewaldt, pp. 3,20-7,14):

The first thing to address is what is meant by the word physis, from which some of the ancient philosophers were called physikoi? It will become clear to you why I am saying this if you read their writings, called Periphyseôs. For it is clear that what they are discussing is the primary substance: the substance which they say is the ungenerated and eternal cause underlying all generated and perishable bodies, and the features that in virtue of their own particular structure constitute each generated and perishable thing. Once known, these features also lead to a knowledge of other things which are not proper to each substance. For this is what makes the teaching on the nature of each existing thing complete, even if someone explains just one or two features in some detail. 
And this is what men are accustomed to say $\langle$ when they want to $\rangle$ show something about the nature of something, just as the Poet does; for he says (Odyssey 10,302-304):

"As the Argus slayer, having spoken clearly, furnished a medicine, pulling it from the earth, and showed to me its physis."

The poet goes on to say:

"The root was black, and the blossom resembled milk."

Likewise, those who wrote about herbs, or about plants in general, taught about the observable nature of each of these plants (what qualities they have to someone touching, tasting, smelling or seeing them), explaining its property either internally (to the plant) or applied to the outside. For the observable nature of each existing thing lies in these qualities. However, the nature that goes beyond this is primary. This is what I was talking about above and concerning which Plato advises anyone who wishes to discuss something methodically to familiarise himself with. I will transcribe for you this passage of his (Phaedrus 270c-d):

"So do you think it is possible to understand the physis of the soul properly, apart from understanding the nature of the whole?-If Hippocrates, of the Asclepiadian family, is to be believed, not even the body can be understood other than by this method.- - He is correct, my friend. Still, we need, in addition to Hippocrates, to investigate reason and see whether it is in agreement with him.-Yes.-What, then, do Hippocrates and true reasoning say concerning the inquiry into nature? For is it not necessary that the nature of anything whatsoever be understood in this way? First whether the thing concerning which we want to become experts and make others experts too is simple or complex. Then, if it is simple, to examine what power it has by nature for acting, and in respect of what, and what it has for being affected, and by what; while if it has many forms, we must list them, and then do for each of them what we did in the case of the single one, namely see what it is of a nature itself to bring about $\langle$ on what $\rangle$, or to be affected, and by what."

This passage from Plato's Phaedrus teaches you the meaning of the term physis and also how one must investigate its essence methodically.

You will find all these things written in books titled Peri physeōs by the ancient philosophers: Empedocles, Parmenides, Melissus, Alcmaeon, and Heraclitus. Some of them wrote not just one, but several books devoted to this investigation; some, like Epicurus, even wrote a great many. He begins as do all the others, with the question of whether the thing whose nature we are attempting to discover is single and simple, or whether it is something constructed from some simple principles prior to it - principles which those who came after the Ancients tended to call stoicheia ('elements'), just as with regard to speech, grammarians say that the elements are 24 in number, i.e. the simple and primary parts which cannot be divided into other parts in the way syllables can. For if you remove the first element, sigma, from the syllable 
-stra-, what is left behind, the residual 'tra', is still a syllable. And so again, if you remove the first letter, -t-, from this -tra-, as a remainder from this you will still have 'ra', which is capable of being divided. However, you cannot divide the -a-nor show it to be composed of two or three sounds, as many others are. For it is one indivisible sound in itself, not simply with respect to length, as we and many other philosophers have shown elsewhere, but with respect to form alone. This, then, is also the way in which those who say that the four elements of generated and perishable bodies are air, fire, earth and water, since none of them can be cut further into more forms, posit these as primaries of physiologia (science of nature). There is a first method of conceiving the smallest bodies based on size; the second, in turn, is based on quality, as has been shown with elements of speech. And the physikoi philosophers disagreed with each other, some supposing that the elements are the smallest parts in generated and perishable bodies based on size, and some that they are the smallest based on quality. Now in the first book of Medical Terms, ${ }^{16}$ I discussed the meaning of the term stoicheion, just as I did in relation to the term physis in the fifth book. But our present discourse is concerned not with appellations and meanings, but with the actual facts about the parts which are minimal, whether in respect of quantity or quality, from which is generated the first composition of generated bodies, which Aristotle and I call ['perceptible elements' and] 'uniform parts'. There is another, second, composition of bodies which we call organic parts: the hand, leg, and eye, the tongue and lung and heart, and liver and spleen, kidneys, stomach, womb, and other such things. For the primary nature of such organs is comprised of primary elements and uniform parts, which Plato was accustomed to call 'first-born' (prôtogona). The difference between these bodies has also been discussed in a certain treatise, but I will recapitulate the main points for the sake of clarity in exposition. Bone and cartilage and tendon are uniform parts, as are membrane, fat and flesh, both that which is moulded around the sinews of the muscles, which themselves are uniform parts, and that around the viscera, which Erasistratus calls parenchuma. And at the beginning of the treatise On the Therapeutic Method, in which I explained what sort of thing this method is, it was shown that it is impossible to discover by means of indication the treatment of the uniform bodies without knowing whether each of them is simple, or is composed of several elements, and whether these are mixed all the way through, or only touching each other. And it has also been shown that some doctors, including Erasistratus, are semidogmatics, treating diseases of organic parts theoretically, but not treating those of uniform parts, or else treating them empirically. And (it has been shown that) most of them do not know how diseases of the organic parts differ from those arising in uniform parts, just as they do not know the number of each of these two categories of disease. However, you, my friends, possess one of my treatises, On the Differences of Diseases, and a not insignificant treatise

16 The Greek text of this treatise is lost. 
concerning remedies, which I have called On The Therapeutic Method. Both these and other things require that we discuss the nature of the body, which is taught in the present treatise."

From this long discussion on the concept of nature in philosophers and doctors, the first thing to note is the breadth of Galen's view on the history of philosophy. During his analysis of physis, he quotes Greek philosophers from the archaic, classical and Hellenistic periods. Amongst the pre-Socratic philosophers, whom he calls 'the ancient philosophers' ( $\tau \hat{\omega} \nu \pi \alpha \lambda \alpha i \hat{\omega} \nu \varphi i \lambda 0-$ $\sigma o ́ \varphi \omega \nu)$, he alludes to a series of works by five of them, whom he quotes in the following order: Empedocles, Parmenides, Melissus, Alcmaeon and Heraclitus. The presence of Melissus of Samos in this list is not surprising, since he is quoted at the start of Hippocrates' The Nature of Man, the text he is commenting on. ${ }^{17}$ It is interesting to note, meanwhile, that already by Galen's time, these philosophical treatises were known under the title of Peri physeōs, 'On Nature'.

For the classical period, Galen mentions Plato and Aristotle. He points out in both philosophers the expression they use to describe the elements whose union comprises the physis of engendered bodies.

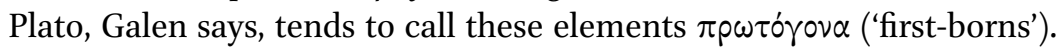
As a matter of fact, this term that Galen says is usual in Plato appears only

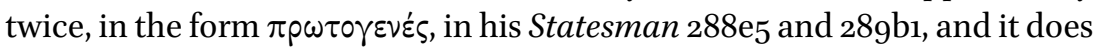
not mean the elements of engendered bodies, but rather materials such as gold, silver, cork and papyrus that Plato qualifies as the primary possession of men and exempt from composition (288 e $5 \pi \hat{\alpha} \nu \tau \dot{\partial} \pi \rho \omega \tau 0 \gamma \varepsilon v \varepsilon \dot{\varsigma} \varsigma \dot{\alpha} \nu \theta \rho \omega \dot{\pi} \pi \circ \varsigma$ $\chi \tau \hat{\eta} \mu \alpha$ xai $\alpha \sigma \dot{v} v \theta \varepsilon \tau \sigma v)$. Thus, Galen distorts reality, transposing the term from the inanimate to the living. However, we might say that Galen preserves the spirit of Plato's text to the extent that materials such as gold, silver and cork are simple elements for the formation of instruments (oppravov, see Statesman $287 \mathrm{~d}$ ), just as human materials such as bones and flesh serve for the formation of organs. The same Greek word oppravov means both instrument and organ.

From Aristotle, Galen takes two expressions, according to the text edited

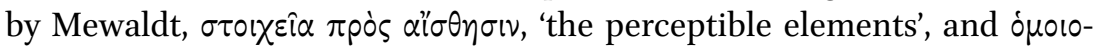
$\mu \varepsilon p \hat{\eta}$, 'the uniform parts'. ${ }^{18}$ The first expression presents a serious problem

${ }^{17}$ Hippocrates, The Nature of Man, ch. 1 ed. Jouanna, p. 166,11.

18 Ed. Mewaldt, p. 6,15. This is not the only treatise where Galen says that he takes the term 'uniform parts' from Aristotle; see De sanitate tuenda 6.2 (6.384,4f. K.); Koch CMG V, 4 , 2 (1923). 
because it is not Aristotelian, but Galenic, as Mewaldt highlights in his Testimonia. Should we think that Galen attributed his own vocabulary to Aristotle? This is what we would be tempted to think, if we accepted the text edited by Mewaldt. However, a consultation of the critical apparatus

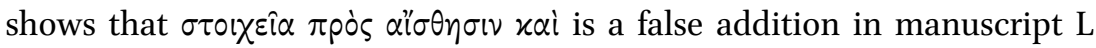
(Laurentianus gr. 59, 14), as shown by the agreed omission of these words in two other manuscripts, V (Vaticanus gr. 282) and R (Vaticanus Reg. 173), and the Arabic translation. ${ }^{19}$ Thus, Galen attributes only the expression $\delta \mu о ю \mu \varepsilon p \hat{\eta}$ to Aristotle, which is a direct and correct reading. Aristotle uses the word to mean the elements of the living being. For example, in On the Parts of Animals (2.2, 647b1o ff.), Aristotle lists amongst the soft and moist uniform parts the blood, ichor, fat, marrow, semen, bile, milk and flesh, and amongst the dry and hard uniform parts, the bone, spine, nerves and blood vessels. The two lists of Aristotle and Galen are comparable, although Galen does not include the humours amongst the uniform parts.

Hellenistic philosophy is represented by a single name, Epicurus. To conclude his overview of the history of philosophy, we note that Galen distinguishes between the vocabulary of the ancient philosophers and their successors with which they designate the elements. He noted that $\sigma \tau 0$ ¿ $\chi$ Eiov was not used by ancient philosophers, whilst it became normal in their successors. Thus, we come to appreciate, thanks to the discussion of physis in Greek philosophy and medicine, the close attention Galen paid to the history of philosophical language and the appearance of certain terms during the development of this history of philosophy, such as $\sigma \tau 0 \chi \chi \varepsilon \hat{\imath} 0 \mathrm{v}$ and

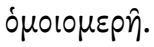

However, despite this sensibility to the evolution of language, Galen's synthetic way of thinking becomes manifest in his insistence on the persistence in the meaning of physis and, above all, in the method of the analysis of physis.

Concerning the word physis, Galen refers not only to the titles of the works of ancient philosophers, but also to Homer, of whom he quotes a passage from the Odyssey $(10,304)$, which contains the first attestation in Greek literature of the word physis. However, Galen is concerned less with the words themselves than to the notion they refer to and, above all, to the method required to discover this notion. It is no accident that the method

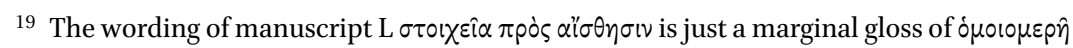
that has slipped into the text. Compare Galen, The Best Constitution of Our Bodies 2 (4.741,10 f.

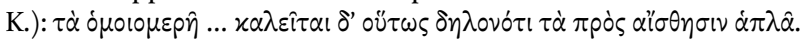


related to the discovery of an object's physis is linked in this preamble to the famous passage of Plato's Phaedrus where Hippocrates is mentioned. Galen sees it as the clearest statement of the philosophical method of researching physis, i.e. the analysis into simple elements and the determination of the dynamis of these simple elements. However, according to Galen, although the formulation of the method is Platonic, the existence of the method predates Plato. The method is common to all the ancient physikoi and it was continued by those who followed them. Epicurus, from this point of view, used the same method. The only difference between the philosophers concerns their definition of the elements, some defining them by their quantity, and others by their quality. However, Galen does not dwell on these differences in the preamble, but emphasises continuity. In this context, we might be surprised not to find mention of The Nature of Man, to which it acts as a preamble. Yet the connection is made visible a short while later in the same preamble when Galen, in his discussion of the problem of the authenticity of the first part of the treatise, which he attributes to Hippocrates, takes the quotation from the Phaedrus to highlight that the research method of the physis of the body, which Plato attributes to Hippocrates, alludes to the start of The Nature of Man. Here is the passage from the preamble (ed. Mewaldt pp. 8,19-9,11):

The first part of the treatise (sc. The Nature of Man) constitutes, so to say, the foundation $(\kappa p \eta \pi \hat{i} \delta \alpha)$ of the whole of Hippocrates' art. This is why I have said that I am amazed that some people exclude this book as being alien to Hippocrates' thought. ... Almost all other doctors, as I said, apart from a small number, are convinced that the short work The Nature of Man is by Hippocrates; Plato himself knows it. Indeed, in his Phaedrus he writes this short passage that I quoted before, of which this is the beginning:

"Do you think it is possible to understand the physis of the soul properly, apart from the nature of the whole?-If Hippocrates, of the Asclepiadian family, is to be believed, not even the body can be understood other than by this method."

Those who talk random nonsense should pay attention to this passage and consider which of Hippocrates' books concerns the method praised by Plato. For it will become clear that besides the present treatise, The Nature of Man, in no other does Hippocrates investigate first concerning the human body whether it is simple or complex, and then each of the other topics which Plato mentioned, and which I have taught about in my work On The Elements According to Hippocrates, and which I will now demonstrate again, since this is what you have decided.

At the end of his linear explanation of the first part, Galen returns to the method employed by Hippocrates. This long conclusion still has at its heart 
the quotation from Plato's Phaedrus, which Galen quotes again for the third time. Here is the conclusion (ed. Mewaldt, pp. 53,17-55,25):

Hippocrates, having set himself the task to discover the nature of our bodies in this book, used the following method for his discovery: first he has inquired whether it is simple or complex, and then, having found that it is complex, examined the substance of the simple components contained in it, i.e. what sort of substance it is, that is, what power it possesses to be affected by something and to act, and this is why he mentioned the seasons and ages of life, examining how the elements which have been discovered are related to these things. He further discovered that it is necessary to refer to these considerations in the prediction of the resolution of a disease and in its treatment. In his research into the constituting elements of our body, he has kept in mind the elements of the whole, which are truly elements. For when we are speaking loosely, we sometimes call the simple and primary parts in the articulation of any individual subject the elements of that thing, just as we speak of harmonic and rhythmic elements, and arithmetical and geometrical ones, and those of argument and speech and demonstration. Thus Plato says there are a hundred elements of a cart, as Hesiod said when he wrote:

"a hundred planks of the cart."

For not everything which is called in this way an element in each individual case is genuinely simple and primary, but those things common to all things and which are simple and genuinely primary are properly called 'elements'. And Hippocrates named these things after the qualities, hot and cold, wet and dry, and not things intermediate between the extremes, but the extremes themselves, namely fire and earth, water and air.

This is the method that Plato saw fit to imitate $(\mu \mathrm{i} \mu \varepsilon \hat{i} \sigma \theta \alpha \iota)$ in examining the nature of the soul. For no particular thing, he says, can be exactly understood without understanding the nature of the whole. I will transcribe for you the very Platonic passage, which reads as follows:

"So do you think it is possible to understand the physis of the soul properly, apart from understanding the nature of the whole?-If Hippocrates, of the Asclepiadian family, is to be believed, not even the body can be understood other than by this method.- - He is correct, my friend. Still, we need, in addition to Hippocrates, to investigate reason and see whether it is in agreement with him.-Yes.-What, then, do Hippocrates and true reasoning say concerning the inquiry into nature? For is it not necessary that the nature of anything whatsoever be understood in this way? First whether the thing concerning which we want to become experts and make others experts too is simple or complex. Then, if it is simple, to examine what power it has by nature for acting, and in respect of what, and what it has for being affected, and by what; while if it has many forms, we must list them, and then do for each of them what we did in the case of the single one, namely see what it is of a nature itself to bring about $\langle$ on what $\rangle$, or to be affected, and by what. 
Since Plato has written these things, let someone show us in which of Hippocrates' books other than Nature of Man can one find this method; or if indeed he is unable to do so, let him look for no more reputable witness than Plato to the book's authenticity. And furthermore, Plato was born very close to the time of Hippocrates' students, so that if this book were by one of them, he would have written down the name of its author. Indeed, before the kings of Alexandria and Pergamum conceived the ambition of acquiring ancient books, no writing was ever given a false attribution. But as soon as those who began to collect the works of some ancient author for them received remuneration for it, they immediately collected many and falsely attributed them. But these kings came after the death of Alexander, whereas Plato wrote these things before Alexander's reign, when attributions were not yet being forged, but each book displayed its proper author on the title-page. So Plato agrees that one must investigate the nature of the soul according to the method that Hippocrates used in the case of the body, and says that this cannot be done properly without knowing the nature of the whole, Some people are so far mistaken as to think that this wonderful method is in fact someone else's, because the one who first discovered such a great and admirable matter would not have shrunk from writing down the demonstration of it. For how is it not great and admirable to discover the elements of generated and destructible bodies? And how would they not be much better established with demonstrations? And how can these things be grasped in not even three hundred complete lines, but many fewer? For it is not likely that Hippocrates would make use of these elements in all of his therapeutic and prognostic investigations as though they had been demonstrated, and yet nowhere have actually provided the demonstration for them.

This new discussion in the conclusion of the first part of Galen's commentary resumes and develops what he had already begun in his preamble on the method of research on physis in The Nature of Man and its relationship with Plato's Phaedrus. However, the The Nature of Man acquires from now on a decisive place in Hippocrates' thought, and Hippocrates acquires a stature that the start of the commentary had not brought to light, and above all an eminent place in this history of philosophical research on physis.

Galen describes the place of The Nature of Man in the work of Hippocrates

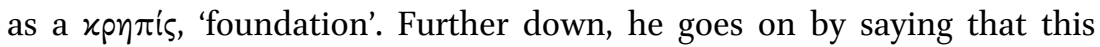
treatise contains the exposition and demonstration of the method of the discovery of the elements of man, a discovery that serves as a basis for all the discoveries which Hippocrates was able to make in treatment and prognosis. Thus, Galen sees in this first part of The Nature of Man the foundation of Hippocrates' medical discoveries, to the extent that there we find the account of human nature and the application of the method of the determination of these elements. 
Galen makes Hippocrates the inventor of the method of philosophical research on nature and sees the Plato of the Phaedrus as an imitator of Hippocrates. Galen uses the verb $\mu \mu \varepsilon \hat{\imath} \sigma \theta \alpha$, 'to imitate', to establish the relationship between Plato's method and that of Hippocrates. We can see here how the important role Platonic philosophy occupies in Galen (a role more important even than Aristotelian philosophy) can only be fully understood in relation to Hippocratic thought. Although it might seem paradoxical, Plato is, in Galen's eyes, a continuator of Hippocrates, author of the start of The Nature of Man. ${ }^{20}$

However, if we compare this role of Hippocrates with the outline that Galen had initially made in his preamble, we cannot help but notice a most remarkable difference. In his outline, Galen insisted on the continuity of the method from the ancient philosophers to those of the Hellenistic period, even seeing in the passage from the Odyssey the beginning of this method, at least for research of the perceptible physis. The passage of Plato's Phaedrus on the method of inquiry into physis was already central, but it did not seem to mark a decisive stage, since Galen already saw in the preSocratic philosophers the application of the method. However, from the moment Galen re-examines the passage of Plato's Phaedrus, identifying the Hippocratic method mentioned by Plato with that of The Nature of Man, he qualifies Plato as an imitator and Hippocrates as the inventor of the method, even if Plato can be credited with transposing the method from the body to the soul. Thus, if Hippocrates was the first to discover this method, as Galen implies, what about the treatises of the physikoi who pre-date Hippocrates? Does this mean that Hippocrates was the inventor of the elements of the body only for humans? Does it mean, rather, that he is the inventor of the inquiry into physis in its perfected form? The answer to this question is awkward. This awkwardness comes from the fact that Galen does not match a traditional view of the history of philosophy with his vaunted view of Hippocrates, whom he sees not only as the origin of medicine, but also of philosophy. However, this view of Hippocrates as both a doctor and philosopher that comes from Galen's commentary on The Nature of Man corresponds to the ideal of a philosopher-doctor that Galen promotes in his

20 Galen also connects the method of Plato in his Phaedrus and that of Hippocrates in his De methodo medendi 1.2 (10,13 f. K.). More generally, Galen thinks that Plato took his principal doctrines from Hippocrates; see De usu partium I 8 (ed. Helmreich 1.11): "Plato was a supporter ( $\zeta \lambda \omega \tau \eta \dot{s})$ of Hippocrates and took from him the most important of his doctrines." These doctrines include the theory of the four humors, the tripartite division of the soul etc. On Platonism in Galen in general, see Ph. De Lacy, "Galen's Platonism," AJPh 93, 1972, pp. 27-39. 
small work dating from the same time, entitled That the Best Doctor is also a Philosopher. ${ }^{21}$ In this short work, Galen returns to the Hippocratic method of knowledge of the physis of the body, which he qualifies as a logical method, saying (ed. I. Mueller, p. 6,14-19):

This same method also teaches what is the nature of the body itself, that which comes from the primary elements which are totally mixed with each other, that of the secondary elements, the perceptible ones, which are also called uniform parts and, in addition to these two, the third, that which comes from the organic parts.

In this passage, Galen systematically summarises and clearly distinguishes the three levels of research on human nature obtained by the logical method. This research comes to correspond, after Galen, with two of the three parts of philosophy, logic and physics.

Galen sees in the Hippocratic treatise The Nature of Man the philosophical foundation of the whole of Hippocrates' medical teaching, the discussion of the method of investigation of physis and of the elementary theory of the human body that serves as a basis for nosology, prognosis and treatment. In this context, we now better understand the energy that Galen puts into showing that the first part of The Nature of Man was written by Hippocrates. In fact, the start of the treatise constitutes the very foundation of the image that Galen has of Hippocrates; it is the pedestal of Hippocrates for Galen. We do not need to point out that this Galenic reading of The Nature of Man hardly corresponds to a modern one. However, my purpose today was not to study the treatise The Nature of Man in itself, but to reconstruct, from the 'transformative' reading that Galen makes in his commentary, ${ }^{22}$ his view of Hippocrates and the central place he assigns him in the history of philosophical and medical inquiry into physis. Although it might seem paradoxical, Hippocrates appears, in the eyes of Galen, as the brilliant precursor of the Platonic diaeresis.

${ }^{21}$ See I. Mueller, Scripta Minora II, pp. 1-8; cf. also E. Wenkebach, "Der hippokratische Arzt als das Ideal Galens," in QSGN, Bd. 3, Heft 4, 1932-1933, p. 155 [363]-175 [383]. On this work, which should be connected with the commentary on Airs, waters, places, see J.Jouanna. "La lecture de l'éthique hippocratique chez Galien" (quoted in n. 1), pp. 230-241, with n. 41 (for bibliography concerning its date), also included in the present volume as ch. 13 .

22 On the notion of 'transformative' reading in Galen, see the thoughts of H. von Staden in the discussion of my paper at the Entretiens de la Fondation Hardt XLIII on "La lecture de l'éthique chez Galien" (quoted in n. 1), p. $252 \mathrm{f}$. 